The University of Southern Mississippi

The Aquila Digital Community

Faculty Publications

3-10-2006

\title{
Cytochrome P4501A is Induced in Endothelial Cell Lines From the Kidney and Lung of the Bottlenose Dolphin, Tursiops truncatus
}

\author{
Rita Anne Garrick \\ Fordham University \\ Bruce R. Woodin \\ Woods Hole Oceanographic Institution \\ Joanna Y. Wilson \\ Woods Hole Oceanographic Institution \\ Bobby L. Middlebrooks \\ University of Southern Mississippi, Bobby.Middlebrooks@usm.edu \\ John J. Stegman \\ Woods Hole Oceanographic Institution
}

Follow this and additional works at: https://aquila.usm.edu/fac_pubs

Part of the Biology Commons

\section{Recommended Citation}

Garrick, R. A., Woodin, B. R., Wilson, J. Y., Middlebrooks, B. L., Stegman, J. J. (2006). Cytochrome P4501A is Induced in Endothelial Cell Lines From the Kidney and Lung of the Bottlenose Dolphin, Tursiops truncatus. Aquatic Toxicology, 76(41337), 295-305.

Available at: https://aquila.usm.edu/fac_pubs/8560

This Article is brought to you for free and open access by The Aquila Digital Community. It has been accepted for inclusion in Faculty Publications by an authorized administrator of The Aquila Digital Community. For more information, please contact Joshua.Cromwell@usm.edu. 
Cytochrome P4501A is induced in endothelial cell lines from the kidney and lung of the bottlenose dolphin, Tursiops truncatus

Rita Anne Garrick ${ }^{1,2}$, Bruce R. Woodin², Joanna Y. Wilson², Bobby L. Middlebrooks ${ }^{3}$ and John J. Stegeman ${ }^{2}$.

${ }^{1}$ Department of Natural Sciences, Fordham University, 113 W. $60^{\text {th }}$ Street, New York, NY 10023, USA, ${ }^{2}$ Department of Biology, Woods Hole Oceanographic Institution, Woods Hole MA 02543, USA, ${ }^{3}$ Department of Biological Sciences University of Southern Mississippi, Hattiesburg MS 39406-0001

Contact author: Rita Anne Garrick

Dept. of Natural Sciences

Fordham University

113 W. $60^{\text {th }}$ Street

New York, NY 10023 USA

212-636-6333

212-636-7213 FAX

rgarrick@whoi.edu
Mailing Address 2005-2006

Biology Department MS\#32

Woods Hole Oceanographic

Institution

Woods Hole, Ma 02543 USA

508-289-2368

508-457-2134 FAX

rgarrick@whoi.edu 


\section{Abstract}

Marine mammals respond to the presence of polycyclic and planar halogenated aromatic hydrocarbons (PAH or $\mathrm{PHAH}$ ) with the induced expression in endothelium of cytochrome P4501A1, regulated through the aryl hydrocarbon receptor (AHR) transcription factor. Physiological responses in other animals, such as edema and inflammation indicate that the endothelium may be compromised by exposure to AHR agonists, which are ubiquitous in the marine environment. In other mammals and fish the cellular and molecular consequences of exposure to AHR agonists have been elucidated in cultured endothelial cells. We have cultured and characterized cetacean endothelial cells (EC) and used them in induction studies. Endothelial cells were cultured from the lung and kidney of the bottlenose dolphin Tursiops truncatus and exposed to the AHR agonists $\beta$-naphthoflavone ( $\beta N F)$ and 2,3,7,8-tetrachlorodibenzo- $p$-dioxin (TCDD). $\beta N F(1-3 \mu M)$ induced significant increases in CYP1A1(O-deethylation of 7-ethoxyresorufin to resorufin;EROD) activity to 3.6 and $0.92 \mathrm{pmol} / \mathrm{mg} / \mathrm{min}$ in lung and kidney EC, respectively. TCDD was more potent than $\beta N F$, and more efficacious, with maximum induction of CYP1A1activity of 10.1 and 15.2 $\mathrm{pmol} / \mathrm{mg} / \mathrm{min}$ in lung and kidney EC at 3-10 $\mathrm{nM}$ TCDD. The differential response indicates that the lung and kidney endothelial cells in culture retain the ability to respond in a selective manner to specific stimuli. Both the molecular mechanisms of induction and the physiological consequences, especially in the vasculature, of toxicant exposure can be studied in this system.

Key words: endothelium, CYP1A, EROD, dioxin, cetacean, microvascular 


\section{Introduction}

Marine organisms are continuously exposed to polycyclic and planar halogenated aromatic hydrocarbons (PAH and $\mathrm{PHAH}$ ) in their environment. The toxicological consequences of experimental exposure to these toxicants in fish and mammals include developmental abnormalities (Guiney et al.,1997), mutagenesis (Shimada and Fujii-Kuriyama,2004), inflammation (Hennig et al.,2002b), and edema (Teraoka et al.,2003). In marine mammals high tissue levels of PHAH, including ortho-substituted polychlorinated biphenyl (PCB) congeners and other organochlorines, have been correlated with compromised immune systems (Lahvis et al.,1995), reproductive abnormalities (Reijnders, 1986), an unusually high incidence of tumors (Martineau et al.,2002) and epizootic outbreaks (Hall et al.,1992; Aguilar and Borell,1994). The strongest molecular effect of exposure to PAHs or PHAHs in vertebrates is the induction of enzymes of the cytochrome P4501A (CYP1A) family, through the aryl hydrocarbon receptor (AHR) transcription factor (Hahn,1998; Mimura and FujiiKuriyama,2003). The level of CYP1A1 induction in laboratory mammals and fish has been shown to depend upon the concentration of the AHR agonist used as an inducer in whole animals and in cells in culture, including in endothelial cells

e.g., (Stegeman et al.,1995; Annas et al.,2000b; Garrick et al.,2005). Toxicant accumulation (Marsili et al.,2001) and the expression of CYP1A1 (Angell et al.,2004) have been documented in cetaceans, primarily in the biopsy samples from field studies; integumentary CYP1A1 expression is primarily in endothelial cells (Angell et al.,2004). Controlled exposure studies that have 
established a causal relation between toxicant dose and CYP1A1 level in laboratory mammals and fish are not possible with cetaceans. Thus, the relation between toxicant levels, AHR activation and the physiological consequences of exposure have been inferred in cetaceans from other types of studies. For example, in liver microsomes from two cetacean species (Delphinapterus leucas and Globicephala melas) CYP1A1 expression level is correlated with the levels in blubber of non-ortho and mono-ortho PCB congeners (AHR agonists) and with the rate of metabolism of these congeners (White et al.,1994; White et al.,2000). The presence of the AHR receptor has been confirmed by cloning of the receptor from the beluga, Delphinapterus leucas (Jensen and Hahn,2001). Godard et al. (2004) demonstrated that in vitro induction of CYP1A1expression by $\beta$ naphthoflavone in skin biopsy slices from sperm whale, Physeter macrocephalus, was dose dependent in endothelial tissue.

The endothelium in many vertebrate tissues is rich in AHR expression and responds to xenobiotic exposure with the induction of CYP1A1enzymes and physiological responses, such as edema and inflammation (Bayou-Denizot et al.,2000; Hennig et al.,2002b), which indicates that the endothelium may be compromised in exposed animals. Cultures of mammalian and teleost endothelial cells, which show induction of CYP1A1 by $\mathrm{PHAH}$ and $\mathrm{PAH}$, are being used to study the mechanisms of the cellular response and the sensitivity of the endothelium in various species to various xenobiotics (Farin et al.,1994; Stegeman et al.,1995; Celander et al.,1997; Annas and Brittebo,1998; BayouDenizot et al.,2000; Annas et al.,2000b; Hennig et al.,2002a; Garrick et al.,2005). 
Chat et al (Chat et al.,1998) used immortalized and freshly isolated rat brain microvessel endothelial cells to demonstrate that there is no loss in functional activity in CYP1A1 and related enymes in these endothelial cells even after 62 passages. Thum et al (Thum et al.,2000) report that in rat aortic endothelial cell cultures loss of induction of CYP1A1 in response to Aloclor 1254 was only seen in cells which no longer tested positive as endothelial cells.

In cultures of cetacean (dolphin) kidney epithelial cells PAH exposure caused DNA damage and inhibited cell growth and exposure to fuel oil caused apoptosis and altered transport and enzyme activities after high exposure levels (Carvan et al.,1995; Pfeiffer et al.,2000; Sweat et al.,2001). However, there are no studies with endothelial cells cultured from cetacean tissues which describe the dose dependent responses to toxicant exposure. This is an important objective given the biological roles of endothelium, the frequent detection of CYP1A1 in endothelium in biopsies and its potential as a marker of exposure in marine mammals (Ben-David et al.,2001; Angell et al.,2004; Godard et al.,2004).

We have developed endothelial cell cultures from tissue samples from the kidney and lung of an Atlantic bottlenose dolphin,Tursiops truncatus (Middlebrooks et al.,1999). We report here the induction of CYP1A1expression and activity in these endothelial cells in response to exposure to $\beta$-napthoflavone $(\beta N F)$ and 2,3,7,8 -tetrachlorodibenzo-p-dioxin (TCDD). 


\section{Materials And Methods}

Chemicals

2,3,7,8-Tetrachlorodibenzo- $p$-dioxin (TCDD) (>98\% pure) was obtained from Ultra Scientific, Hope, RI, USA. 7-Ethoxyresorufin was purchased from Molecular Probes (Eugene, OR). Dimethylsulfoxide (DMSO), $\beta$-napthoflavone $(\beta N F)$ and all other reagents were the highest grade available from Sigma (St. Louis, MO). Cell culture materials from Sigma were Cell Culture Tested. Other sources were noted below.

Culture of Kidney and Lung Cells

Dolphin cell lines were developed from kidney and lung biopsies taken from a stillborn Atlantic bottlenose dolphin calf at Marine Life Aquarium, Gulfport, $\mathrm{MI}$ and transported in physiological saline to the lab at University of Southern Mississippi (Middlebrooks et al.,1999). The parenchymal tissue samples, taken within 24 hours of the delivery, were trypsinized for five hours and cultured in Liebovitz -15 (L-15) complete medium with $10 \%$ fetal bovine serum (Hyclone) in tightly capped flasks (Middlebrooks et al.,1999). Cell lines TuTruK (kidney) and TuTruL (lung) were established from these cells.

Cells from passages 19 for kidney (TuTruK) and 18 for lung (TuTruL) cell lines were selected as the starting cultures for the current studies and were evaluated for heterogeneity by phase contrast microscopy (Garrick,2000; Garrick et al.,2005). The kidney cells appeared to be homogeneous in size and appearance, although not a pure (cloned) culture. The lung cell culture revealed what appeared to be two cell types, based on cell size. Culture conditions were 
changed to those that favored endothelial cell growth: M199SE [Medium 199 with Earle's salts and $20 \mathrm{mM} \mathrm{NaCl}, 20 \mathrm{mM} \mathrm{HEPES}, 26 \mathrm{mM} \mathrm{NaHCO}_{3}, 0.68 \mathrm{mM}$ glutamine, $10 \mu \mathrm{M}$ pyruvate $1 \mathrm{X}$ antibiotic-antimycotic solution (100 U/ml penicillin, $100 \mu \mathrm{M} / \mathrm{ml}$ streptomycin, $2.5 \mu \mathrm{M} / \mathrm{ml}$ amphotericin B)] with $10 \%$ serum (Cosmic Calf Serum, fortified (CCS), Hyclone, Logan, UT) in T-75 flasks and incubated at $37^{\circ} \mathrm{C}$ in $5 \% \mathrm{CO}_{2}$ (Garrick,2000; Garrick et al.,2005).

Endothelial cells can be identified by the uptake pattern of fluorescently labeled acetylated low-density lipoprotein (Dil-Ac-LDL, 1,1'-dioctadecyl-12,3,3',3'-tetramethyl-indocarbocyanide perchlorate acetylated LDL, Biomedical Technologies, Stoughton, MA) (Garrick et al, 2005). The kidney cells were identified as homogeneous endothelial cells with Dil-Ac-LDL uptake when viewed on a Zeiss Axiovert S100 fluorescence microscope. We tested the lung cells with Dil-Ac-LDL and found that the smaller cells took up Ac-LDL and the larger did not. We subcultured the lung cells with differential plating times and by removing the larger cells we were able to obtain a homogeneous cell culture in one passage based on Dil-Ac-LDL uptake. Cells grown from these homogeneous cultures were the lung cells used in all subsequent studies. The cells used in this study were at passages 19-21.

At confluence the cells were subcultured or aliquots cryopreserved in the vapor phase of liquid nitrogen by standard procedures. 
Treatment of Cells

Cells were seeded into 48 well plates (Costar, Cambridge MA)) at a density of $\sim 2 \times 10^{5}$ cells/well and grown to confluence in $0.5 \mathrm{ml}$ of M199SE with $10 \% \mathrm{CCS}$ and incubated at $37^{\circ} \mathrm{C}$ in $\mathrm{CO}_{2}$. Subsequent procedures were as described in Stegeman et al, 1995, for intact cells. At confluence the medium was removed and the cells were rinsed with serum - free M199SE and $0.5 \mathrm{ml}$ of M199SE with 1\% CCS was added to each well. DMSO, or serial dilutions of TCDD or $\beta N F$ dissolved in DMSO, was added to the wells in $2.5 \mu \mathrm{l}$ aliquots from dilutions of stock solutions so that DMSO was present at $0.5 \%(\mathrm{v} / \mathrm{v})$ in all wells except for untreated cells (Stegeman et al.,1995). Each dose was added to 6 wells, the plate was shaken for I min. and the cultures returned to the incubator at $37^{\circ} \mathrm{C}$ in $5 \% \mathrm{CO}_{2}$ for $48 \mathrm{hrs}$. In Stegeman et al. (1995) both $\beta N F$ and TCDD produced induction after a 48 hour exposure. The wells were examined microscopically before and after treatment to confirm the cells were confluent and intact.

Cells that were used for the microsomal preparations were grown in T-75 flasks, exposed to $25 \mu \mathrm{l}$ of the appropriate dosing solution in $5 \mathrm{ml}$ of M199SE (to maintain the $0.5 \%(\mathrm{v} / \mathrm{v})$ of DMSO) with $1 \% \mathrm{CCS}$, shaken for $1 \mathrm{~min}$. and incubated at $37^{\circ} \mathrm{C}$ in $5 \% \mathrm{CO}_{2}$ for 48 hours. The cells were confluent and intact before and after the treatment.

Preparation of microsomes from endothelial cells Microsomal fractions were prepared from endothelial cells treated with chemicals in T-75 flasks. After a 48 hour exposure, the dosing medium was removed and 
the flask was rinsed with serum - free M199SE. One ml of PBS-HEPES pH 7.5 with 2 mM EDTA was added to the flask. The flask was floated on liquid nitrogen to snap freeze the cultures and stored at $-80^{\circ} \mathrm{C}$ until used. Frozen cells were scraped from the flask into buffer, homogenized, sonicated and subcellular fractions obtained by differential centrifugation as described in Stegeman et al.(1995). Pellets were resuspended in buffer (50 mM Tris, pH 7.4, $1 \mathrm{mM}$ dithiothreitol, 1 mM EDTA, 20\% glycerol) and frozen in liquid $\mathrm{N}_{2}$ until used. Protein content was determined using the bicinchoninic acid method, with serum albumin as a standard (BCA ${ }^{\circledR}$ Protein Assay Kit, Pierce, Rockford, IL). Assays

1. EROD activity

The O-deethylation of 7-ethoxyresorufin to resorufin, (EROD) a kinetic measure of CYP1A1activity, was determined fluorometrically in intact cells with a Cytofluor 4000 (Millipore) multiwell plate reader, as described for porcine endothelial cells (Stegeman et al.,1995). Incubation procedures were modified as described earlier (Hestermann et al.,2000; Hestermann et al.,2002; Garrick et al.,2005). At the end of the dosing time the medium was removed and the cells washed with $0.5 \mathrm{ml}$ of phosphate - buffered - saline (PBS) with HEPES pH 7.5 (0.136 M NaCl, $8.1 \mathrm{mM} \mathrm{Na}_{2} \mathrm{HPO}_{4}, 1.47 \mathrm{mM} \mathrm{K}_{2} \mathrm{HPO}_{4}, 2.68 \mathrm{mM} \mathrm{KCl}, 10 \mathrm{mM}$ HEPES).

The EROD reaction was initiated by the addition of $200 \mu \mathrm{l} /$ well of a solution of 7-ethoxyresorufin $(2.67 \mu \mathrm{M}$ in PBS-HEPES at pH 7.8) and monitored kinetically for 20 min. Resorufin standard curves were prepared in PBS-HEPES 
$\mathrm{pH} 7.8$ in wells in each plate. At completion of the EROD assay total protein content was measured in each well with the fluorescamine assay with BSA solutions for the standard curve. EROD activity was calculated as pmol of resorufin produced /mg protein/min as described previously (Kennedy et al.,1993; Stegeman et al.,1995; Hahn et al.,1996; Ganassin et al.,2000).

Significance of the change in the level of EROD activity in cells was tested with the Kruskal-Wallis test with Dunn's as a post-test. for non-parametric ANOVA with GraphPad InStat.

2. NADPH-dependent cytochrome $\mathrm{c}$ reductase activity

$\mathrm{NADPH}$-dependent cytochrome $\mathrm{c}$ reductase was measured in microsomal preparations from both treated and untreated cells by the reduction of horse heart cytochrome $\mathrm{c}$ at $37^{\circ} \mathrm{C}$ by the method described previously (Stegeman et al.,1982; Stegeman et al.,1995). Cuvettes contained $15-20 \mu \mathrm{g}$ of protein in a total volume of $500 \mu \mathrm{l}$. Activity calculated from the change in absorbance at $550 \mathrm{~nm}$ is expressed as $\mathrm{nmol} / \mathrm{mg} / \mathrm{min}$.

\section{Immunoblotting for CYP1A1}

The presence of CYP1A1 was detected by immunoblot analysis of microsomal preparations as described previously, with slight modification (Hahn et al.,1993; Stegeman et al.,1995). Microsomal protein (30 to $70 \mu \mathrm{g})$ and a range of standards of CYP1A from scup (Stenotomus chrysops) were resolved on a 4$20 \%$ acrylamide gradient gel in TRIS-glycine with SDS (Jule,Inc, Milford, CT). Proteins electrophoretically transferred to nitrocellulose (Schleicher \& Schuell, Keene, $\mathrm{NH}$ ) were incubated with monoclonal antibody Mab 1-12-3 against scup 
CYP1A (Park et al.,1986) and a secondary antibody linked to horseradish peroxidase. Mab 1-12-3 strongly recognizes CYP1A1 but not CYP1A2 in mammals (Drahushuk et al.,1999). Detection and quantification of the bands relative to those of scup CYP1A were as before (Stegeman et al.,1995; Garrick et al.,2005).

4. $\mathrm{EC}_{50}$ Calculation

$\mathrm{EC}_{50}$, the inducer concentration producing half maximal induction of EROD activity, was calculated using the curve fitting routine of GraphPad Prism for nonlinear regression sigmoidal dose response. The modified Gaussian equation for $\mathrm{EC}_{50}$ was described in (Stegeman et al.,1995).

\section{Results}

Cell Preparations

Figure 1 shows cultures of the cells from the kidney $(A, B)$ and the lung $(C, D)$ of the bottlenose dolphin. The morphology of the two preparations in the phase contrast micrographs in $A$ and $C$ is similar and cobblestone like, typical of endothelial cells. The appearance of the kidney cells was the same as in the cultures when first received. In contrast to the kidney cells, the lung cell cultures were somewhat heterogeneous when first received. However, non-endothelial cells lifted off more rapidly than endothelial cells and by using differential plating times we were able to obtain a population of EC from the original lung cell culture. In subsequent studies we used only cells passed from the lung endothelial cell cultures that were homogeneous. The uptake of Dil-Ac-LDL by the kidney and lung cells, seen in the fluorescent micrographs in Fig1.B and D, 
was homogeneous and confirmed that these are endothelial cells; however, the vessel type of origin is not clear. The most likely source of the endothelial cells from both the kidney and lung parenchymal tissues was the microvasculature although there is no specific marker, at present, to confirm that cells are microvascular in origin.

Figure 1 here

Induction of CYP1A1 Activity

The kidney and lung cells were grown in 48 well plates and treated for 48 hours with DMSO, TCDD or $\beta N F$. The incubation medium contained $1 \%$ serum to minimize loss of inducer to serum proteins (Hestermann et al.,2000). At the end of the 48 hours the EROD activity (CYP1A1activity) and total protein were measured in each well as described in the Methods.

Table 1 here

The results for EROD activity given in Table 1 indicate that TCDD and $\beta N F$ induce CYP1A1 in the lung and kidney endothelial cells in similar yet distinct ways. These data are averages of from 6 to 18 measurements in individual wells at a given inducer concentration from experiments in different plates of cells. As reported for other cells, the EROD activity level can vary from plate to plate (Bello et al.,2001; Garrick et al.,2005) but the relative activity at the different inducer concentrations (shape of the dose-response curve) remains the same. When DMSO-treated, both kidney and lung cells had negligible levels of EROD activity (Table 1): if averaged across all plates, a total of 24 wells, EROD activity with DMSO present was $0.435+0.12 \mathrm{pmol} / \mathrm{mg} / \mathrm{min}$ in lung cells and $0.431+0.06$ 
$\mathrm{pmol} / \mathrm{mg} / \mathrm{min}$ in kidney cells. Incubation with increasing concentrations of $\beta \mathrm{NF}$ resulted in a small but significant increase in CYP1A1 activity in both kidney and lung cells to a maximal EROD activity beyond which higher concentrations of $\beta N F$ resulted in a decreased level of CYP1A1 activity. The maximal EROD activity in response to $\beta N F$ in the lung cells was about $3 X$ greater than it is in the kidney cells.

TCDD also produced a dose-dependent increase in EROD activity to a maximum response and then a decrease in activity at the highest TCDD concentrations in both the lung and kidney endothelial cells. The level of activity induced was similar for the kidney and lung cells for most of the concentrations of TCDD used. The peak activity appeared to be higher in the kidney than in the lung endothelial cell but this difference was not significant. The maximal rates of EROD activity in cells treated with TCDD for $48 \mathrm{hrs}$ were $15.2 \mathrm{pmol} / \mathrm{mg} / \mathrm{min}$ for kidney and $10.1 \mathrm{pmol} / \mathrm{mg} / \mathrm{min}$ for lung endothelial cells.

Figure 2 here

The normalized data for CYP1A1 (EROD) induction with $\beta N F$ and with TCDD are plotted in Figure $2 \mathrm{~A}$ and $\mathrm{B}$. The two lines plotted in Fig 2A suggest a difference in the $\mathrm{EC}_{50} \mathrm{~S}$ (concentration at half maximal peak response) for $\beta \mathrm{NF}$ with the two cell populations; but with the current number of data points we consider these values, $0.15 \mu \mathrm{M}$ for kidney cells and $0.24 \mu \mathrm{M}$ for lung cells, to be estimates rather than firm numbers and do not consider this difference significant. 
The similarity in the response to TCDD is seen in $2 \mathrm{~B}$ where the lines for the normalized data for the kidney and lung endothelial cells superimpose. The $\mathrm{EC}_{50}$ for CYP1A1 induction by TCDD in the kidney cells is $0.019 \mathrm{nM}$ TCDD and in the lung cells is $0.018 \mathrm{nM}$ TCDD. Thus, TCDD was more potent than $\beta N F$ with $\mathrm{EC}_{50}$ in $\mathrm{nM}$ vs. $\mu \mathrm{M}$ range respectively (Fig. $2 \mathrm{~A}$ and $2 \mathrm{~B}$ ), and more efficacious (Hestermann et al.,2000), with maximum induction of CYP1A1 activity 3-10 times higher in lung and kidney endothelial cells (Table 1).

NADPH-dependent cytochrome c reductase activity

The levels of NADPH cytochrome c (P450) reductase activity measured in microsomal preparations from treated and untreated kidney and lung endothelial cells were similar, $30 \mathrm{nmoles} / \mathrm{mg} / \mathrm{min}$ in each. These rates are similar to the $40 \mathrm{nmol} / \mathrm{mg} / \mathrm{min}$ reported in porcine aortic endothelial cells (Stegeman et al.,1995) and should be similarly effective in supporting CYP1A1activity. Immunochemical Identification of CYP1A

Microsomal preparations from kidney and lung cells exposed to $10 \mathrm{nM}$ TCDD for 48 hours in T-75 flasks were immunobloted with the Mab 1-12-3 that strongly recognizes CYP1A1 but not CYP1A2 in mammals. No band was detected in microsomes from DMSO treated cells, in accord with the low basal levels of EROD activity. As shown in Fig. 3, immunoblotting confirmed that CYP1A1 is present in bottlenose dolphin kidney and lung endothelial cells exposed to TCDD concentrations that produce significant increases in EROD activity.

Figure 3 here 
Amounts of CYP1A1 in unknowns can be estimated based on the relative staining densities of the scup CYP1A standards. The CYP1A1 equivalents were calculated to be $1.2 \mathrm{pmol} / \mathrm{mg}$ in kidney endothelial cells and $1.7 \mathrm{pmol} / \mathrm{mg}$ in lung endothelial cells treated with $10 \mathrm{nM}$ TCDD, a dose at which the EROD activity is similar in the two types of endothelial cells.

\section{Discussion}

Cultures of endothelial cells from the lung and kidney of the bottlenose dolphin, Tursiops truncatus, exposed to the AHR agonists $\beta N F$ and TCDD responded with induction of CYP1A1as indicated by EROD activity and immunodetection of CYP1A. Based on EROD activity and immunoblot results, CYP1A1 levels were negligible in both kidney and lung cells treated with DMSO. In both kidney and lung endothelial cells the levels of CYP1A1 induced after TCDD treatment were about 10 -fold greater than after $\beta N F$ treatment. The induction of EROD activity in the kidney and lung endothelial cells allowed us to establish the first dose response curves for an AHR agonist in endothelial cells cultured from a cetacean. The dose-response curves demonstrate that endothelial cells originating from different tissues (lung and kidney) of the bottlenose dolphin respond similarly to TCDD induction but significantly different maximal CYP1A1 induction in response to $\beta N F$. This system provides the opportunity to both characterize factors that may determine the similarities and difference in response and to explore how CYP1A1functions (e.g. production of reactive oxygen or biotransformation) may be associated with conditions in which the endothelium is compromised. 
A consistent observation in vertebrates from fish to mammals is that the endothelium in many organs is a major extra-hepatic site of CYP1A1induction by PHAHs or PAHs (Stegeman et al., 1989; Guiney et al.,1997; Wilson et al.,2005). The induction of CYP1A1 in endothelium by $\beta N F$ was observed also in vitro in skin tissue slices from whales (Godard et al.,2004). In cetacean populations, in vivo, an elevated level of AHR receptor agonists can be correlated with the expression of CYP1A1detected immunohistochemically in integument samples (Angell et al.,2004). Different levels of expression of CYP1A1 were reported for endothelium from several organs in populations of beluga whale in which the contaminant levels were known (Wilson et al.,2005). The supplementary data (doi:10.1289/eph.7664 at http://dx.doi.org/) lists the different levels in endothelium from kidney and lung.

A differential induction of CYP1A1expression in endothelium in different vessels in the vasculature has been observed in vivo, after either acute or chronic exposure to AHR agonists (Schlezinger and Stegeman,2000a; Wilson et al.,2005), and has been reported in vitro for endothelial cells cultured from arteries, veins, capillaries, endocardium and the microvasculature of vertebrates (Annas et al.,2000b; Granberg et al.,2003; Garrick et al.,2005). In cetaceans, exposure to toxicants also results in differential expression of CYP1A1in endothelium, i.e., primarily in the microvascular or capillary endothelium, in the skin (Angell et al.,2004; Godard et al.,2004) and in other organs (Wilson et al.,2005). The availability of bottlenose dolphin lung and kidney endothelial cells 
now allows studies of toxicant response in cetacean endothelial cells from two organs.

There is negligible CYP1A1activity (EROD) or protein present (Fig 3) in either lung or kidney endothelial cells not exposed to inducer; this is similar to most other mammalian endothelial cell cultures (Stegeman et al.,1995; Annas et al.,2000b). In endothelial cells originally cultured from tissue from mature female eels (Garrick et al.,2005), in human aortic endothelial cells (Celander et al.,1997) and in integument tissue slices from sperm whale field samples (Godard et al.,2004), there is a low expression of CYP1A1 in endothelium even with no inducer present in the test system. This low level of CYP1A1 expression in endothelial cells or cetacean tissue slices has been interpreted as low levels of environmental induction in field samples, presence of some additional unknown inducers, or constitutive expression (Godard et al.,2004; Garrick et al.,2005). We do question whether this very low level of CYP1A1 activation would have significant physiological or toxicological consequences in the vasculature.

The peak EROD rates induced with $\beta N F$ are $3 X$ higher in the dolphin lung endothelial cells than in the kidney endothelial cells, 3.36 and $0.92 \mathrm{pmol} / \mathrm{mg} / \mathrm{min}$ respectively, and are similar to EROD activity reported for other mammalian endothelial cells, 1 to $6 \mathrm{pmol} / \mathrm{mg} / \mathrm{min}$ (Stegeman et al.,1995; Celander et al.,1997; Annas et al.,2000b). Endothelial cells cultured from two different vascular beds of the American eel also have significantly different EROD activity after exposure to $\beta N F$, i.e., $135 \mathrm{pmol} / \mathrm{mg} / \mathrm{min}$ in endocardial cells and negligible activity in capillary cells from the rete mirabile (Garrick et al.,2005). 
The maximum CYP1A1 activity induced by TCDD in both dolphin lung and kidney endothelial cells is similar to that induced in kidney endothelial cells from the American eel (16 pmol/mg/min) and considerably lower than that in eel endocardial cells (142 pmol/mg/min)(Garrick et al.,2005) but well within the range reported for mammalian large vessel endothelial cells, 3 to $30 \mathrm{pmol} / \mathrm{mg} / \mathrm{min}$ (Stegeman et al.,1995; Celander et al.,1997; Annas et al.,2000b). TCDD is known to be a potent inducer of CYP1A1and this is reflected in the $\mathrm{EC}_{50} \mathrm{~s}$ of $0.019 \mathrm{nM}$ and $0.018 \mathrm{nM}$ TCDD for lung and kidney EC, respectively, that are within the range of $\mathrm{EC}_{50} \mathrm{~s} 0.015$ to $0.045 \mathrm{nM}$ TCDD reported for other endothelial (Stegeman et al.,1995; Garrick et al.,2005) or non-endothelial cells (Hahn et al.,1996; Bello et al.,2001; Carlsson and Part,2001; Tom et al.,2001). Thus, the endothelial cells from the dolphin respond to in vitro induction by TCDD at a concentration similar to endothelial cells from other mammals and teleosts. In summary, we have shown that endothelial cell lines grown from the microvasculature of the lung and the kidney of the same bottlenose dolphin calf respond to $\beta N F$ induction with a maximum level of CYP1A1 activity similar to other mammalian endothelial cells, although there is a threefold difference in the maximum activity of the two dolphin cell lines. The response to TCDD induction is quite similar in the two dolphin endothelial cell lines and is similar to the responses in other mammalian cells. We observed functional diversity in different areas of the vasculature in response to induction with AHR agonists in endothelial cell lines cultured from the American eel (Garrick et al.,2005). The data from the dolphin cell endothelial cell lines suggest that there are tissue 
specific differences in the response in marine mammals to some AHR agonists and we now have the ability to explore this question on the cellular level.

. The similarity in the response to TCDD in the kidney and lung endothelial cells suggest that the response to pHAHs may be similar in other endothelial and that this might extend to skin endothelial cells in biopsies. Differences in the $\beta N F$ response lead to the question of whether the response to PAHs might differ and whether this difference may be seen in skin endothelial cells as well. There is need to develop additional cultures of cells from cetaceans in order to explore the organ and species differences in susceptibility to AHR agonists that is suggested by field studies.

While the difference in response to $\beta N F$ in these cell populations is intriguing, the similarity in their responses could provide important insights into the pathophysiology of the endothelium. For instance, CYP1A1expression is linked to an inflammatory response both in vivo and in vitro but the consequences of inflammation can be quite different if it occurs in the brain or lung compared to in striated muscle tissue. If there is constitutive expression of CYP1A1in some species or a statistically significant but very low level of induction of CYP1A1 in some organs, are there physiological consequences of this in the vasculature of that animal or organ?

In conclusion, we can now extend the study of the effects of toxicant exposure in cetaceans to in vitro studies with endothelial cell lines. This will allow us to explore such questions as inducer structure-activity relationships, the basis for the toxic equivalency approach and to explore further the consequences of 
AHR action and CYP1A1induction on endothelial cells from different parts of the vasculature, an important physiological question. 


\section{Acknowledgements:}

Part of this work was completed during a faculty fellowship from Fordham University for RAG. The Faculty Research Council of Fordham University provided partial support for RAG. This research was supported by NIH grant 5P42-ES07381 and by U.S.EPA grant R827102-01-0. This research is an outgrowth and continuing impact of Sea Grant Number Grant No. NA90AA-D-SG480, project NA86RG0075-R/P61. Biological materials from Tursiops truncatus were received under permit No. 939-682-00 (NOAA) to WHOI (JJS). Dr. Leslie. D Garrick and Dr. Mark E. Hahn are gratefully acknowledged for reading and commenting on the manuscript. James Saint John participated in the study with support from an Ambrose Summer Research Award from Fordham University. 


\section{References}

Aguilar, A. and Borell, A., 1994. Abnormally high polychlorinated biphenyl levels in striped dolphins (Stenella coeruleoalba) affected by the 1990-1992 Mediterranean epizootic. Science of the Total Environment 154: 237-247.

Angell, C. M., Wilson, J. Y., Moore, M. J. and Stegeman, J. J., 2004. Cytochrome P450 1A1 expression in cetacean integument: Implications for detecting contaminant exposure and effects. Marine Mammal Science 20(3): 554566.

Annas, A. and Brittebo, E. B., 1998. Localization of cytochrome P4501A1 and covalent binding of a mutagenic heterocyclic amine in blood vessel endothelia of rodents. Toxicology 129: 145-156.

Annas, A., Granberg, A. L. and Brittebo, E. B., 2000b. Differential response of cultured human umbilical vein and artery endothelial cells to AhR receptor agonist treatment: CYP-dependent activation of food and environmental mutagens. Toxicol Appl Pharmacol 169: 94-101.

Bayou-Denizot, C., Daval, J.-L., Netter, P. and Minn, A., 2000. Xenobioticmediated production of superoxide by primary cultures of rat cerebral endothelial cells, astrocytes and neurons. Biochim Biophys Acta 1497: 115-126.

Bello, S., Franks, D. G., Stegeman, J. and Hahn, M. E., 2001. Acquired resistance to ah receptor agonists in a population of Atlantic killifish (Fundulus heteroclitus) inhabiting a marine superfund site: In vivo and in 
vitro studies on the inducibility of xenobiotic matabolizing enzymes.

Toxicological Sciences 60: 77-91.

Ben-David, M., Kondratyuk, T., Woodin, B. R., Snyder, P. W. and Stegeman, J. J., 2001. Induction of cytochrome P450 1A1 expression in captive river otters fed prudoe bay crude oil:Evaluation by immunohistochemistry and quantitative rt-pcr. Biomarkers 6(3): 218-235.

Carlsson, C. and Part, P., 2001. 7-ethoxyresorufin o-deethylase induction in rainbow trout gill epithelium cultured on permeable supports:

Asymmetrical distribution of substrate metabolites. Aquat Toxicol 54: 2938.

Carvan, M. J., Flood, L. P., Campbell, B. D. and Busbee, D. L., 1995. Effects of benzo(a)pyrene and tetrachlorodibenzo(p)dioxin on fetal dolphin kidney cells: Inhibition of proliferation and initiation of DNA damage. Chemosphere 30(1): 187-198.

Celander, M., Weisbrod, R. and Stegeman, J. J., 1997. Glucocorticoid potentiation of cytochrome P4501A1 induction by 2,3,7,8tetrachlorodibenzo-p-dioxin in porcine and human endothelial cells in culture. Biochem Biophys Res Commun 232(3): 749-53.

Chat, M., Bayol-Denizoi, C., Suleman, G., Roux, F. and Minn, A., 1998. Drug metabolizing enzyme activities and superoxide formation in primary and immortalized rat brain endothelial cells. Life Sci 62(2): 151-163.

Drahushuk, A. T., McGarrigle, B. P., Slezak, B. P., Stegeman, J. J. and Olson, J. R., 1999. Time- and concentration-dependent induction of CYP1A1 and 
cyp1a2 in precision-cut rat liver slices incubated in dynamic organ culture in the presence of 2,3,7,8-tetrachlorodibenzo-p-dioxin. Toxicology and Applied Pharmacology 155: 127-138.

Farin, F. M., Pohlman, T. H. and Omiencinski, C. J., 1994. Expression of cytochrome p450s and microsomal epoxide hydrolase in primary cultures of human umbilical vein endothelial cells. Toxicol. Appl. Pharmacol. 124: $1-9$.

Ganassin, R. C., Schirmer, K. and Bols, N. C., 2000. Cell and tissue culture. In: G. K. Ostrander.38. Academic Press, San Diego, 631-651.

Garrick, R. A., 2000. Isolation and culture of capillary endothelial cells from the eel, Anguilla rostrata. Microvasc Res 59: 377-385.

Garrick, R. A., Woodin, B. R. and Stegeman, J. J., 2005. Cytochrome P4501A induced differentially in endothelial cells cultured from Anguilla rostrata. In Vitro Cell Dev Biol-Animal 41: 57-63.

Godard, C. A., Smolowitz, R. M., Wilson, J. Y., Payne, R. S. and Stegeman, J. J., 2004. Induction of cetacean cytochrome P4501A1 by $\beta$-naphthoflavone exposure of skin biopsy slices. Toxicological Sciences 80(2): 268-275.

Granberg, L., Ostergren, A., Brandt, I. and Brittebo, E. B., 2003. CYP1A1 and cyp1b1 in blood-brain interfaces: CYP1A1-dependent bioactivation of 7,12-dimethylbenz(a)anthracene in endothelial cells. Drug Metab Dispos 31(3): 259-65.

Guiney, P. D., Smolowitz, R. M., Peterson, R. E. and Stegeman, J. J., 1997. Correlation of 2,3,7,8-tetrachlorodibenzo-p-dioxin induction of cytochrome 
P4501 A in vascular endothelium with toxicity in early life stages of lake trout. Toxicol Appl Pharmacol 143(2): 256-73.

Hahn, M. E., 1998. The aryl hydrocarbon receptor: A comparative perspective. Comp. Biochem. Physiol. Part C Pharmacol. Toxicol. Endocrinol 121(2353).

Hahn, M. E., Lamb, T. M., Schultz, M. E., Smolowitz, R. M. and Stegeman, J. J., 1993. Cytochrome P4501A induction and inhibition by 3,3',4,4'tetrachlorobiphenyl in an ah receptor-containing fish hepatoma cell line (PLHC-1). Aquat. Toxicol. 26: 185-208.

Hahn, M. E., Woodward, B. L., Stegeman, J. J. and Kennedy, S. W., 1996. Rapid assessment of induced cytochrome P4501 A (CYP1A) protein and catalytic activity in fish hepatoma cells grown in multi-well plates. Environ. Toxicol. Chem. 15(4): 582-591.

Hall, A. J., Law, R. J., Wells, D. E., Harwood, J., Ross, H. M., Kennedy, S., Allchin, C. R., Campbell, I. A. and Pomeroy, P. P., 1992. Organochloride levels in common seals (phoca vitulina) which were victims and survivors of the 1988 phocine distemper epizootic. Science of the Total Environment 115: $145-162$.

Hennig, B., Hammonck, B. D., Slim, R., Toberak, M., Saraswathi, V. and Robertson, L. W., 2002a. PCB-induced oxidative stress in endothelial cell: Modulation by nutrients. Int J Hyg Environ Health 205: 95-102. 
Hennig, B., Meerarani, P., Slim, R., Toberak, M., Daugherty, A., Silverstone, A. and Robertson, L. W., 2002b. Proinflammatory properties of coplanar PCBs: In vitro and in vivo evidence. Toxicol Appl Pharmacol 181: 174-183.

Hestermann, E. V., Stegeman, J. J. and Hahn, M. E., 2000. Relative contributions of affinity and intrinsic efficacy to aryl hydrocarbon receptor ligand potency. Toxicol Appl Pharmacol 168(2): 160-172.

Hestermann, E. V., Stegeman, J. J. and Hahn, M. E., 2000. Serum alters the uptake and relative potencies of halogenated aromatic hydrocarbons in cell culture bioassays. Toxicol Sci 53(2): 316-25.

Hestermann, E. V., Stegeman, J. J. and Hahn, M. E., 2002. Serum withdrawal leads to reduced aryl hydrocarbon receptor expression and loss of cytochrome P4501A inducibility in PLHC-1 cells. Biochem Pharmacol 63(8): 1405-14.

Jensen, B. and Hahn, M. E., 2001. cDNA cloning and characterization of a high affinity aryl hydrocarbon receptor in the cetacean, the beluga, Delphinapterus leucas. Toxicological Sciences 64: 41-56.

Kennedy, S. W., A. Lorenzen, James, C. A. and Collins, B. T., 1993. A rapid and sensitive cell culture bioassay for measuring ethoxyresorufin-o-deethylase (erod) activity in cultured hepatocytes exposed to halogenated aromatic hydrocarbons extracted from wild bird eggs. Chemosphere 27: 367-373.

Lahvis, G. P., Wells, R. S., Kuehl, D. W., Stewart, J. L., Rhinehart, H. L. and Via, C. S., 1995. Decreased lymphocyte responses in free-ranging bottlenose dolphins (Tursiops truncatus) are associated with increases 
concentrations of PCBs and DDT in peripheral blood. Environmental Health Perspectives 103 Suppl 4: 67-72.

Marsili, L., Caruso, A., Fossi, M. C., Zanardelli, M., Politi, E. and Focardi, S., 2001. Polycyclic aromatic hydrocarbons (pahs) in subcutaneous biopsies of Mediterranean cetaceans. Chemosphere 44: 147-154.

Martineau, D., Lemberger, K., A., D., Labelle, P., Lipscomb, T. P., Michel, P. and Mikaelian, I., 2002. Cancer in wildlife, a case study: Beluga from the St. Lawrence estuary, Quebec, Canada. Envionmental Health Perspectives 110: $285-292$.

Middlebrooks, R., Colvocoresses, J. and Patterson, R. A. (1999). Susceptibility of two developmental cell lines from Tursiops truncatus to a range of mammalian viruses. Abstracts of the 13th Biennial Conference on the Biology of Marine Mammals.

Mimura, J. and Fujii-Kuriyama, y., 2003. Functional role of AhR in the expression of toxic effects by TCDD. Biochim Biophys Acta 1619: 263-268.

Park, S. S., Miller, H., Klotz, A. V., Kloepper-Sams, P. J., Stegeman, J. J. and Gelboin, H. V., 1986. Monoclonal antibodies to liver microsomal cytochrome $p-450$ e of the marine fish Stenotomus chrysops (scup): Cross reactivity with 3-methylcholanthrene induced rat cytochrome P-450. Arch Biochem Biophys 249(2): 339-50.

Pfeiffer, C. J., Sharova, L. V. and Gray, L., 2000. Functional and ultrastructural cell pathology induced by fuel oil in cultured dolphin renal cells. Ecotoxicology and Environmental Safety 47: 210-217. 
Reijnders, P. J. H., 1986. Reproductive failure in common seals feeding on fish from polluted coastal waters. Nature 324: 456-457.

Schlezinger, J. J. and Stegeman, J. J., 2000a. Dose and inducer-dependent induction of cytochrome P450 1A in endothelia of the eel, including in the swimbladder rete mirabile, a model microvascular structure. Drug Metab Dispos 28(6): 701-8.

Shimada, T. and Fujii-Kuriyama, Y., 2004. Metabolic activation of polycyclic aromatic hydrocarbons to carcinogens by cytochromes P450 1A1 and 1B1. Cancer Sci 95(1): 1-6.

Stegeman, J. J., Hahn, M. E., Weisbrod, R., Woodin, B. R., Joy, J. S., Najibi, S. and Cohen, R. A., 1995. Induction of cytochrome P4501A1 by aryl hydrocarbon receptor agonists in porcine aorta endothelial cells in culture and cytochrome P4501A1 activity in intact cells. Mol Pharmacol 47(2): 296-306.

Stegeman, J. J., Miller, M. R. and Hinton, D. E., 1989. Cytochrome P4501A1 induction and localization in endothelium of vertebrate (teleost) heart. Mol. Pharmacol. 36: 723-729.

Stegeman, J. J., Woodin, B. R., Klotz, A. V., Wolke, R. E. and Orme-Johnson, N. R., 1982. Cytochrome P-450 and monooxygenase activity in cardiac microsomes from the fish Stenotomus chrysops. Mol. Pharmacol. 21: 517526. 
Sweat, J. M., Dunigan, D. D. and Wright, S. D., 2001. Characterization of kidney epithelial cells from the florida manatee, trichecus manatus latirostris. In Vitro Cell and Developmental Biology- Animal 37: 386-394.

Teraoka, H., Dong, W., Tsujimoto, Y., Iwasa, H., Endoh, D., Ueno, N., Stegeman, J. J., Peterson, R. E. and Hiraga, T., 2003. Induction of cytochrome P450 $1 \mathrm{~A}$ is required for circulation failure and edema by $2,3,7,8-$ tetrachlorodibenzo-p-dioxin in zebrafish. Biochem Biophys Res Commun 304: 223-228.

Thum, T., Haverich, A. and Borlak, J., 2000. Cellular dedifferentiation of endothelium is linked to activation and silencing of certain nuclear transcription factors:Implication for endothelial dysfunction and vascular biology. FASEB Journal 14: 740-751.

Tom, D. J., Lee, L. E., Lew, J. and Bols, N. C., 2001. Induction of 7ethoxyresorufin-o-deethylase activity by planar chlorinated hydrocarbons and polycyclic aromatic hydrocarbons in cell lines from the rainbow trout pituitary. Comp Biochem Physiol A Mol Integr Physiol 128(2): 185-98.

White, R. D., Hahn, M. E., Lockhart, L. L. and Stegeman, J. J., 1994. Catalytic and immunochemical characterization of hepatic microsomal cytochromes P450 in beluga whale, Delphinapterus leucas. Tox. App. Pharm. 126: 4557.

White, R. D., Shea, D., Schlezinger, J. J., Hahn, M. E. and Stegeman, J. J., 2000. In vitro metabolism of polychlorinated biphenyl congeners by beluga whale (Delphinapterus leucas) and pilot whales (globicephalea melaena) 
and relationship to cytochrome P450 expression. Comp Biochem Physiol Part C Pharmacol. Toxicol. Endocrinol 126: 267-284.

Wilson, J. Y., Cooke, S. R., Moore, M. J., Martineau, D., Mikaelian, I., Metner, D. A., Lockhart, W. L. and Stegeman, J., 2005. Systemic effects of arctic pollutants in beluga whales indicated by CYP1A1 expression. Environmental Health Perspectives 113(11): 1-6. 


\section{Table 1}

Production of resorufin from 7-ethoxyresorufin in lung and kidney endothelial cells. Cells are induced in $\mathbf{4 8}$ well plates for $\mathbf{4 8}$ hours.

Values are mean \pm SE; $n$ is a minimum of 6 wells, a maximum of 18

$$
\mathrm{pmol} / \mathrm{mg} / \mathrm{min}
$$
$\mu \mathrm{M} \beta \mathrm{NF}$
DMSO
0.01
0.1
1
3
10

\section{Lung Cells}

$\begin{array}{ccccccc}\text { Average } & 0.90 & 1.55 & 1.57 & 1.20 & 3.63^{* *} & 2.47^{* *} \\ \text { +SE } & 0.28 & 0.25 & 0.40 & 0.09 & 0.37 & 0.26\end{array}$

\section{Kidney Cells}

$\begin{array}{ccccccc}\text { Average } & 0.20 & 0.44 & 0.29 & 0.92^{* *} & 0.33 & 0.47 \\ \text { +SE } & 0.06 & 0.19 & 0.19 & 0.23 & 0.26 & 0.52\end{array}$

nM TCDD

DMSO $\quad 0.01$

0.1

0.3

1

3

10

15

30

\section{Lung Cells}

Average

+SE

0.30

0.05

1.60

0.25

Kidney Cells

Average $\quad 0.4$ +SE $\quad 0.05$

0.69

0.49

1.61

0.78

5.21

0.51

$6.27^{\text {** }}$

$7.03^{\star *}$

$10.12^{\text {** }}$

$6.09^{* *}$

3.69

0.75

0.97

1.27

0.52

0.50

** Significant difference among column means at $p \leq 0.002$ with the Kruskal-Wallis test with Dunn's as a post-test for non-parametric ANOVA calculated with GraphPad InStat. 


\section{Figure Captions}

Figure 1. Micrographs of kidney $(A, B)$ and lung $(C, D)$ endothelial cells of the bottlenose dolphin Tursiops truncatus. $(A)$ and $(C)$ are phase contrast micrographs and (B) and (D) are fluorescence micrographs showing the uptake of Dil-acetylated-LDL viewed on a Zeiss Axiovert S100 at 10X. The uptake pattern for Dil-Ac-LDL in (B) and (D) is characteristic of endothelial cells.

Figure 2. Normalized plots of EROD activity after $\beta N F$ and TCDD exposure. Normalized plots (percent of maximal response) of the EROD activity (mean $\underline{+}$ SE) from Table 1 (with log transformation of inducer concentration) are given for $\beta N F(A)$ and TCDD (B) for the lung and kidney endothelial cells. Normalized plots of the data are used to calculate $\mathrm{EC}_{50}$. $\mathrm{EC}_{50}$ calculated for $\beta \mathrm{NF}$ is 0.15 and 0.24 $\mu \mathrm{M}$ for kidney and lung cells respectively and $\mathrm{EC}_{50}$ for TCDD is 0.019 and 0.018 nM for kidney and lung cells.

Figure 3. Immunoblot of CYP1A1 in microsomes isolated from kidney or lung endothelial cells. Cultures were exposed to TCDD for 48 hours as described in the methods. Microsomes from: (A) cells after DMSO; (B) 0.4 pmol scup CYP1A standard; (C) kidney cells after $10 \mathrm{nM}$ TCDD, $75 \mu \mathrm{g}$ protein, $1.4 \mathrm{pmol} / \mathrm{mg}$; (D) lung cells after10 nM TCDD, $75 \mu \mathrm{g}$ protein, 1.7pmol/mg (D). The dolphin CYP1A1 band migrated similar to scup CYP1A at $54 \mathrm{kD}$. 
Figure 1

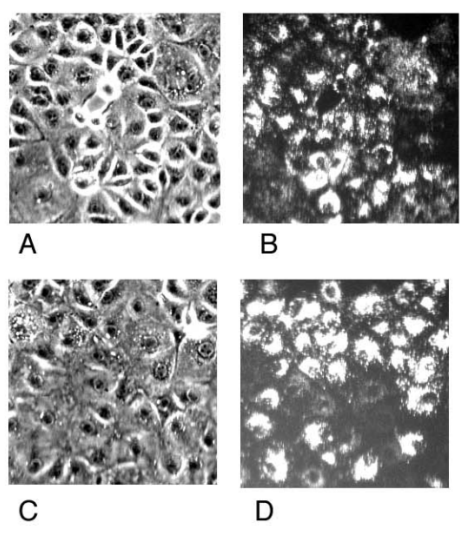


Figure 2

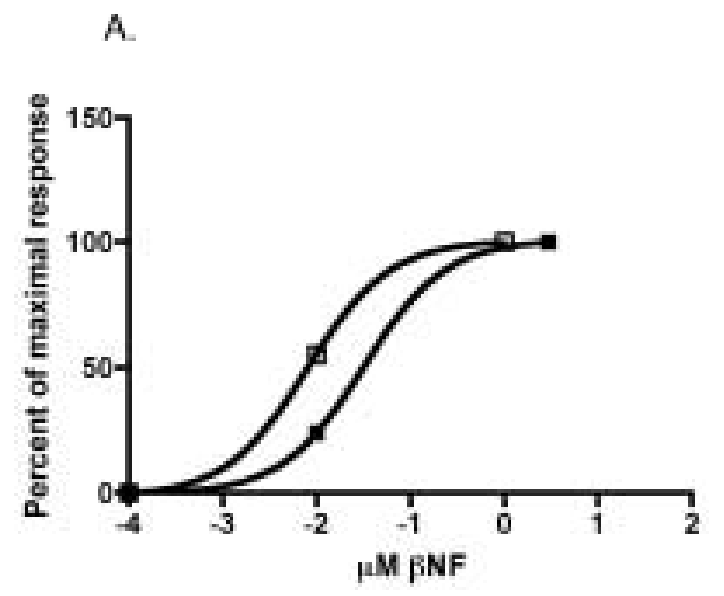
- Lung
- Kidney

B.

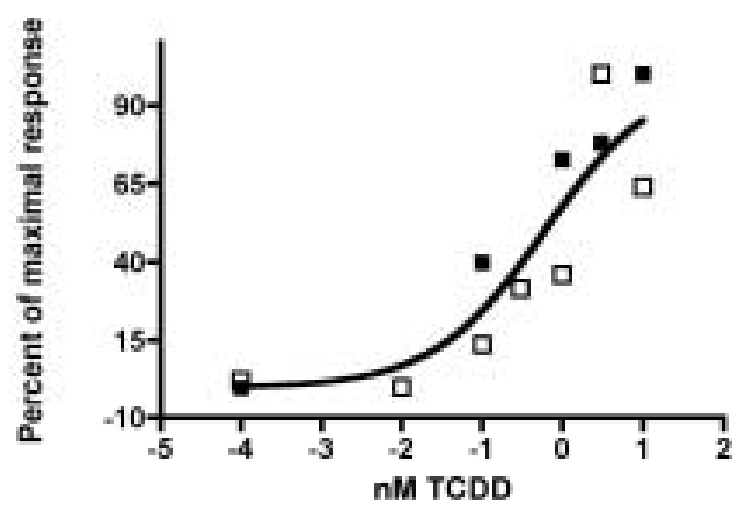

c Kidney

- Lung 
Figure 3

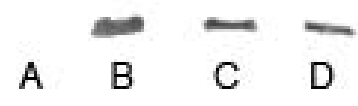

